https://helda.helsinki.fi

\title{
Is home monitoring of inflammatory bowel disease feasible? A randomized controlled study
}

\section{Puolanne, Anna-Maija}

2019-07-03

Puolanne , A-M , Kolho , K-L , Alfthan , H \& Färkkilä , M 2019 , ' Is home monitoring of inflammatory bowel disease feasible? A randomized controlled study ', Scandinavian Journal of Gastroenterology , vol. 54 , no. 7 , pp. 849-854 . https://doi.org/10.1080/00365521.2019.1618910

http://hdl.handle.net/10138/326390

https://doi.org/10.1080/00365521.2019.1618910

unspecified

acceptedVersion

Downloaded from Helda, University of Helsinki institutional repository.

This is an electronic reprint of the original article.

This reprint may differ from the original in pagination and typographic detail.

Please cite the original version. 
Is home monitoring of inflammatory bowel disease feasible? A randomized controlled study

Anna-Maija Puolanne M.D. ${ }^{1}$, Kaija-Leena Kolho Ph.D. ${ }^{2}$, Henrik Alfthan Ph.D. ${ }^{3}$, Martti Färkkilä Ph.D. ${ }^{4}$

${ }^{1}$ Helsinki University Hospital, Jorvi Hospital, Clinic of Gastroenterology, Turuntie 150, 02740 Espoo, Finland

${ }^{2}$ University of Helsinki and Helsinki University Hospital, Helsinki, Finland and Tampere University and Tampere University Hospital, Tampere, Finland

${ }^{3}$ Department of Clinical Chemistry, University of Helsinki, Helsinki, Finland

${ }^{4}$ Department of Medicine, Division of Gastroenterology, Helsinki University Hospital, Helsinki, Finland

Corresponding author

Name: Anna-Maija Puolanne

Address: Helsinki University Hospital, Jorvi Hospital, Clinic of Gastroenterology, Turuntie 150, 02740 Espoo, Finland

Telephone: +358 503290945

Requests for reprints should be sent to e-mail: anna-maija.puolanne@helsinki.fi

including in total 3735 words 


\begin{abstract}
Objectives The aim of this prospective study was to evaluate the home monitoring with a rapid fecal calprotectin test combined with a symptom questionnaire in patients with colonic IBD in real-life setting.
\end{abstract}

Methods We randomized 180 patients with colonic IBD in a study or a control group. The home monitoring patients performed the fecal calprotectin test and filled in a symptom questionnaire every second month and in cases with increasing symptoms. The control patients filled in the symptom questionnaire at baseline and at 6 and 12 months as well as for the appointment at the outpatient clinic. The study duration was 12 months.

Results The patient adherence to the self-monitoring program was low. Patients with a higher disease burden were more adherent than patients with better health-related quality of life, but otherwise there were no significant factors predicting the adherence. The home monitoring patients had fewer contacts with the outpatient clinic, but the disease course between the home monitoring and the control group were similar.

Conclusions The self-monitoring of IBD activity with a combination of a rapid fecal calprotectin home test and a symptom questionnaire provides an option for individualized care for IBD patients. However, the adherence to the self-monitoring program remains a challenge.

Key words: Crohn’s disease, fecal calprotectin, disease activity, ulcerative colitis 


\section{Introduction}

Traditionally, the treatment and monitoring of inflammatory bowel disease (IBD) has been based on scheduled visits to an outpatient clinic. The increasing number of IBD patients ${ }^{12}$ results in the need for new monitoring and treatment strategies. In recent studies, selfmonitoring of IBD has shown to be feasible. ${ }^{345}$

Fecal calprotectin (FC) is the most used non-invasive method for monitoring inflammatory activity in IBD. ${ }^{6789}$ To make the fecal testing more feasible, several rapid FC tests have been developed and validated. ${ }^{1011} 12$

Previously, we validated a symptom questionnaire for monitoring IBD, suitable for both UC and CD. ${ }^{13}$ The clinical activity of the disease was determined with 6 questions concerning IBD symptoms during the last week: general well-being, abdominal pain, bowel movements at daytime and night-time, presence of blood in stools, and the impact of the IBD on daily life assessed by the VAS (visual analog scale). ${ }^{13}$

The aim of this study was to evaluate the feasibility of a self-monitoring strategy using a rapid FC test and a symptom questionnaire in patients with colonic IBD. 


\section{Materials and methods}

Between April 2015 and December 2016, adult patients with colonic IBD from Helsinki University Hospital, Finland, were enrolled. Exclusion criteria were extensive colon resection or colectomy. Patients were randomized with closed envelopes in blocks of ten into the home monitoring group and control group (1:1). Patients were not stratified with the IBD subtype, disease severity or medication. The study period was 12 months.

Patients in the home monitoring group were instructed to perform a semi-quantitative FC test with cut-offs of FC $<50 \mu \mathrm{g} / \mathrm{g}, 50-200 \mu \mathrm{g} / \mathrm{g}$ and $>200 \mu \mathrm{g} / \mathrm{g}$ (Prevent ID CalDetect, Preventis, Immunodiagnostics AG, Germany) ${ }^{12}$ and to fill in a symptom questionnaire ${ }^{13}$ and a healthrelated quality of life questionnaire (15D-questionnaire) ${ }^{14}$ sent by e-mail every other month and with increasing of the symptoms. They reported the results to the nurse by simply filling in the attached documents. When performing the home test, they also provided a stool sample to the clinical laboratory for measuring the FC with an ELISA test. For analysis, the ELISA FC results were divided with the same cut-offs as the CalDetect results. In addition, FC was measured centrally using the CalDetect.

The control patients filled in the symptom questionnaire and the 15D-questionnaire at baseline, and at 6 and 12 months, and for the appointment at the gastroenterology outpatient clinic. 
For analysis, the symptom questionnaire was divided into two parts: the patient-reported symptoms (symptom score) (scale 0-15 points, higher score worse), and the influence of the disease in daily life, measured by VAS (scale 1-7, higher score worse). Remission was defined as the symptom score of 0-3 points, and a change of $\geq 2$ points was considered clinically significant. ${ }^{13} \mathrm{~A}$ change of $\geq 0.03$ in the total $15 \mathrm{D}$ score (scale 0 - 1 , lower score worse) was considered clinically important. ${ }^{14} 15$

At the beginning of the study, the patients got the schedule of the study and training about the study protocol and the FC testing. Patients were not reminded of performing the stool tests or filling in the questionnaires, but they were advised to contact the nurse by phone or e-mail if they had problems concerning their bowel disease (alarming symptoms; IBD symptoms and the CalDetect-result $>200 \mu \mathrm{g} / \mathrm{g}$ in two consecutive measurements performed in two days interval; or the result of the symptom questionnaire $\geq 2$ points higher than the previous result). After the end of the study, patients were asked their opinion about study settings.

Statistical analysis

The Mann-Whitney U and the Kruskall-Wallis tests served to analyze differences between groups for continuous and ordinal variables. The Fisher's exact tests were used to analyze differences in dichotomous variables or in variables with nominal categories. The Wilcoxon signed rank tests served to determine differences between two tests performed on the same sample. The Spearman's rank correlation coefficient was calculated to assess correlations between the two variables. A Kaplan-Meier survival curve was drawn to analyze the compliance of the two groups of patients. Results were analyzed with IBM SPSS (v.24, IBM Corp, New York). 


\section{Ethical considerations}

All patients provided their written informed consent prior to enrolment. The Ethics

Committee of the Helsinki University Hospital, Helsinki, Finland, approved the study protocol (189/13/03/01/2014). 


\section{Results}

\section{Patients}

Of the 322 patients invited to the study, 142 patients (44\%) refused to participate or never responded. The eligible 180 patients were randomized into the home monitoring group (89 patients) or control group (91 patients) (Figure 1).

\section{Patient adherence}

In total, 63 home monitoring patients and 60 control patients $(69 \%$ of the included 180 patients) started the study, and were included in the analysis. The demographic data of the patients are presented in Table 1 . In the home monitoring group, 24 patients (38\%) and in the controls 12 patients $(20 \%)$ continued the study for 12 months $(\mathrm{p}=0.001)$ (Figure 2$)$. The median duration of the study was 10 months for the home monitoring patients and 5.5 months for the controls $(\mathrm{p}<0.001)$. Those who participated in the study for 6 months or more, were considered as compliants ( $71 \%$ in the home monitoring group and $46 \%$ in the controls, $\mathrm{p}=0.005$ ), and the rest as non-compliants. Compliant patients were older than non-compliants (mean age 38 years vs 31 years, respectively, $95 \%$ CI 35-40 and 26-36, p=0.013), but otherwise there were no differences between compliants and non-compliants stratified with the IBD-subtype, sex, age-group, disease duration or medication.

\section{Symptoms}

During the study, 428 symptom questionnaires were completed (mean 3

questionnaires/patient). The median symptom score was 1 point (range $0-11$ ), and the median 
VAS was 2 (range 1-7). The baseline VAS was higher in those patients who continued the study compared to those who dropped out after the baseline (mean 2.58 (95\% CI 2.17-2.98) and 2.08 (1.81-2.42) respectively, $\mathrm{p}=0.058)$. Compliant home monitoring patients reported higher baseline VAS than non-compliant patients (mean 2.73 (95 \% CI 0.915-0.959) and 1.81 (0.886-0.951) respectively, $\mathrm{p}=0.019)$. The results of the symptom scores, VAS scores and 15D scores are presented in Table 2.

\section{Health-related quality of life}

A total of 420 15D-questionnaires were completed (mean 3 questionnaires/patient). There were no differences in the results of the $15 \mathrm{D}$ scores between the groups at any point of the study.

\section{Fecal calprotectin}

During the study, 63 home monitoring patients performed 301 CalDetect-tests (mean 5 tests/patient) (Table 4, supplemental material). The median result was FC 50-200 $\mu \mathrm{g} / \mathrm{g}$, and there was no significant difference in the baseline results between compliants and noncompliants $(\mathrm{p}=0.630)$. During the study, 10 patients $(16 \%)$ performed 12 extra CalDetecttests because of worsening symptoms and, as expected, the FC in these tests was higher (FC $>200 \mu \mathrm{g} / \mathrm{g}$ in $60 \%$ of extra tests vs. in $27 \%$ of the routine tests). At the study end, there were numerically less FC values $>200 \mu \mathrm{g} / \mathrm{g}$ compared to the baseline (17\% vs. $26 \%$ of the results, $\mathrm{p}=0.739)$. 
The home monitoring patients sent 264 stool samples to the laboratory, compared to 310 tests performed at home. The median ELISA FC of the home monitoring patients was $67 \mu \mathrm{g} / \mathrm{g}$ (range 1-3834). The correlation between ELISA FC and CalDetect made in the laboratory was statistically significant and slightly better than the correlation between ELISA FC and CalDetect made by patients at home $(r=0.740$ and 0.417 respectively, $\mathrm{p}<0.05)$.

\section{Disease course and activity}

The numbers of relapses, contacts to the outpatient clinic, laboratory visits and hospitalizations are presented in Table 3. Disease activity was similar in both groups. During the study, 46 patients fulfilled the criteria for clinically active disease ( 25 in the home monitoring and 21 in the control group). Twenty-three patients had more than 2 points' raise in the two consecutive symptom scores, which was regarded as clinically significant; 14 in the home monitoring group and 9 in the control group. As many as 17 of 24 patients $(71 \%)$ who filled in extra symptom questionnaires because of worsening symptoms had a symptom score $<3$ points, indicating clinical remission despite the symptoms.

Visits, phone calls and e-mails

There were 281 visits to the outpatient clinic (mean 2.3 visits/patient, range $0-7$ ). In the control group, $40 \%$ of the patients had more than 2 visits, compared to $24 \%$ in the home monitoring group $(\mathrm{p}=0.05)$. Sixty-four patients made 182 phone calls to the outpatient clinic (mean 4 phone calls/patient, range 1-14). Of all phone calls, 66 (24\%) were made because of worsening symptoms (no statistical difference between the groups). 
In total, 54 patients sent 210 e-mails (mean 3.8 mails/patient, range 1-24), the controls sending more e-mails per patient than home monitoring patients (mean 4.9 and 2.8, respectively, $\mathrm{p}=0.180)$.

\section{Visits to the laboratory}

There were 803 laboratory visits (mean 6.5 visits/patient, range 1-20). Of all visits, $87 \%$ were planned at inclusion, mainly for drug safety control, and $13 \%$ were extra visits due to the symptoms. The numbers of the laboratory visits were comparable between the groups (392 in home monitoring group and 411 in controls, $\mathrm{p}=0.636$ ), but extra tests were more common in the home monitoring (61) than in the control group (42) $(\mathrm{p}=0.024)$.

\section{Patient opinions on home-monitoring}

After completing the follow-up, questionnaires on patient opinions on home-monitoring were sent by e-mail to all the 123 patients who started the study, including the control patients as well. No reminders were sent. Only 25 patients responded, 16 (64\%) being from the home monitoring group. Of the respondents, $56 \%$ had completed the 12 months follow-up. More than $80 \%$ of the respondents considered the self-monitoring strategy and the questionnaires simple. Most of the patients $(71 \%)$ preferred e-mail contacts to the outpatient clinic instead of phone contacts, and $66 \%$ wanted to continue the use of e-mail in non-urgent matters. The views were similar in the home monitoring and control groups. None of the home monitoring patients considered the fecal testing uncomfortable. Eighteen percent considered the technical performance of the test complicated, and $46 \%$ considered the interpretation of the test results difficult. More than half of the patients $(57 \%)$ wished to continue the fecal home testing in the future, and $62 \%$ recommended it to other patients as well. 


\section{Discussion}

The primary aim of this study was to evaluate the feasibility of the self-monitoring strategy in a real-life setting. The percentage of patients (44\%) who never responded to the invitation letter was comparable with earlier studies with up to $35-50 \%$ of patients not reached. ${ }^{316}$ The drop-out rate in our study was higher than in some earlier studies (71\% in total; $62 \%$ in the home monitoring group and $80 \%$ in the controls), ${ }^{417} 18$ but it was in line with the large feasibility trial showing up to $74 \%$ drop-out rates. ${ }^{19}$

The baseline influence of IBD in daily life was higher in the patients who continued the study for more than 6 months than in those who dropped out after the baseline, even if there was no difference in the baseline FC or the symptom score. It seems that the patients having a higher disease burden are more adherent and motivated to do the home-monitoring than those patients who do not experience any problems or inconvenience with their disease.

We could not demonstrate any differences in the disease activity between the home monitoring and control patients, which can be due to the low number of compliant patients. Moreover, even if the patients made phone calls and e-mails because of worsening symptoms, they had not filled in the symptom score and therefore did not fulfill the defined criteria for clinically active disease.

The FC level measured with the home test was slightly lower at the end of the study than at the baseline, but this did not reach clinical significance. The control patients sent more e- 
mails concerning their disease and had more appointments at the outpatient clinic than the home monitoring patients, which proves that home-monitoring strategy may aid in resourcing health-care.

We are aware of the limitations of our study. We did not have the possibility to construct an internet portal designed for this purpose, but patients sent the questionnaires and the results of the FC tests to the nurse by e-mail, which many of them found unpractical. Half of the patients found the results of the semi-quantitative FC test difficult to interpret.

To the best of our knowledge, our study is among the first studies to evaluate the home monitoring strategy in a real-life setting in all subtypes of colonic IBD regardless of the disease severity or medication. In previous studies, the self-monitoring of IBD has shown to be a promising means for the more patient-centered follow-up than routine visits to the outpatient clinic. However, we still do not know which patients are suitable for selfmonitoring. The adherence to the self-monitoring program remains a challenge, and we could not find any factors predicting the adherence. The easy accessibility of the monitoring program and simultaneous feedback of the disease activity may increase patient motivation and adherence but needs further consideration. 
Funding

This work was supported by grant from the Helsinki University Hospital Research Fund (TYH2015405). 


\section{Acknowledgements}

We thank our RN Pirkko Tuukkala, Virpi Pelkonen and Sari Karesvuori and Anne Nikkonen for their help and assistance.

A.-M.P. designed the study, performed the statistical analysis, and drafted and completed the manuscript. K.-L. K. participated in designing and supervision of the study and helped to draft the manuscript. H.A. performed and analyzed the rapid fecal tests and helped to draft the manuscript. M.F. designed and supervised the study and helped in drafting the manuscript. All authors have read and approved the final manuscript. 


\section{Disclosure of interest}

The authors report no conflict of interest. 


\section{References}

(1) Jussila A, Virta LJ, Kautiainen H, Rekiaro M, Nieminen U, Färkkilä M. Increasing incidence of inflammatory bowel diseases between 2000 and 2007: a nationwide register study in Finland. Inflamm Bowel Dis 2012;18(3):555-561.

(2) Burisch J, Munkholm P. The epidemiology of inflammatory bowel disease. Scand J Gastroenterol 2015 08/03;50(8):942-951.

(3) Elkjaer M, Shuhaibar M, Burisch J, Bailey Y, Scherfig H, Laugesen B, et al. E-health empowers patients with ulcerative colitis: a randomised controlled trial of the web-guided 'Constant-care' approach. Gut 2010 December 01;59(12):1652-1661.

(4) Aguas M, Del Hoyo J, Faubel R, Nos P. Use of telemedicine in inflammatory bowel disease: a real monitoring option? Expert Review of Gastroenterology \& Hepatology 2016 08/02;10(8):879-881.

(5) Vinding KK, Elsberg H, Thorkilgaard T, Belard E, Pedersen N, Elkjaer M, et al. Fecal Calprotectin Measured By Patients at Home Using Smartphones--A New Clinical Tool in Monitoring Patients with Inflammatory Bowel Disease. Inflamm Bowel Dis 2016 Feb;22(2):336-344.

(6) Roseth AG, Schmidt PN, Fagerhol MK. Correlation between faecal excretion of indium111-labeled granulocytes and calprotectin, a granulocyte marker protein, in patients with inflammatory bowel disease. Scand J Gastroenterol 1999;34:50-54.

(7) Tibble JA, Sigthorsson G, Bridger S, Fagerhol MK, Bjarnason I. Surrogate markers of intestinal inflammation are predictive of relapse in patients with inflammatory bowel disease. Gastroenterology 2000 7;119(1):15-22. 
(8) Molander P, Färkkilä M, Ristimäki A, Salminen K, Kemppainen H, Blomster T, et al. Does fecal calprotectin predict short-term relapse after stopping TNF $\alpha$-blocking agents in inflammatory bowel disease patients in deep remission? J Crohn's Colitis 2015;Jan 9(1):3340.

(9) Heida A, Knol M, Kobold AM, Bootsman J, Dijkstra G, van Rheenen PF. Agreement Between Home-Based Measurement of Stool Calprotectin and ELISA Results for Monitoring Inflammatory Bowel Disease Activity. Clinical Gastroenterology and Hepatology 2017 Available online 10 June 2017.

(10) Elkjaer M, Burisch J, Voxen Hansen V, Deibjerg Kristensen B, Slott Jensen J-, Munkholm P. A new rapid home test for faecal calprotectin in ulcerative colitis. Aliment Pharmacol Ther 2009;31:323-330.

(11) Rogler G, Aldeguer X, Kruis W, Lasson A, Mittmann U, Nally K, et al. Concept for a rapid point-of-care calprotectin diagnostic test for diagnosis and disease activity monitoring in patients with inflammatory bowel disease: Expert clinical opinion. J Crohn's Colitis 2013;7:670-677.

(12) Puolanne A, Kolho K, Alfthan H, Ristimäki A, Mustonen H, Färkkilä M. Rapid faecal tests for detecting disease activity in colonic IBD. Eur J Clin Invest 2016;46(10):825-832.

(13) Puolanne A, Kolho K, Alfthan H, Ristimäki A, Färkkilä M. Rapid Fecal Calprotectin Test and Symptom Index in Monitoring the Disease Activity in Colonic Inflammatory Bowel Disease. Dig Dis Sci 2017;62(11):3123-3130.

(14) Sintonen H. The 15D instrument of health-related quality of life: properties and applications. Ann Med 2001;33(5):328-336. 
(15) Haapamäki Johanna, Andrea T, Harri S, Barner-Rasmussen Nina, Färkkilä MA.

Health-related quality of life among patients with primary sclerosing cholangitis. Liver Int 2015 08/12; 2018/03;35(9):2194-2201.

(16) Robinson A, Thompson DG, Wilkin D, Roberts C. Guided self-management and patientdirected follow-up of ulcerative colitis: a randomised trial. Lancet 2001;358:976-981.

(17) Cross RK, Jambaulikar G, Langenberg P, Tracy JK, Collins JF, Katz J, et al.

TELEmedicine for Patients with Inflammatory Bowel Disease (TELE-IBD): Design and implementation of randomized clinical trial. Contemporary Clinical Trials 2015 5;42:132144.

(18) de Jong MJ, van der Meulen-de Jong,Andrea E., Romberg-Camps MJ, Becx MC, Maljaars JP, Cilissen M, et al. Telemedicine for management of inflammatory bowel disease (myIBDcoach): a pragmatic, multicentre, randomised controlled trial. The Lancet 2017 2-8 September 2017;390(10098):959-968.

(19) Bossuyt P, Pouillon L, Bonnaud G, Danese S, Peyrin-Biroulet L. E-health in inflammatory bowel diseases: More challenges than opportunities? Digestive and Liver Disease 2017 Available online 24 August 2017. 
Table 1. Demographic data of the patients who started the study

\begin{tabular}{|c|c|c|c|c|c|}
\hline & $\begin{array}{l}\text { Total, } \\
\mathrm{n}=123\end{array}$ & $\begin{array}{c}\text { Home } \\
\text { monitoring, } \\
\text { compliant, } \\
\text { n=45 }\end{array}$ & $\begin{array}{c}\text { Home } \\
\text { monitoring, } \\
\text { non- } \\
\text { compliant, } \\
\text { n=18 }\end{array}$ & $\begin{array}{l}\text { Control, } \\
\text { compliant, } \\
\text { n=28 }\end{array}$ & $\begin{array}{l}\text { Control, } \\
\text { non- } \\
\text { compliant, } \\
\text { n=32 }\end{array}$ \\
\hline Diagnosis, n (\%) & & & & & \\
\hline $\mathrm{CD}$ & $31(25)$ & $13(29)$ & $8(44)$ & $4(14)$ & $6(19)$ \\
\hline $\mathrm{UC}$ & $89(73)$ & $32(71)$ & $10(56)$ & $22(79)$ & $25(78)$ \\
\hline IBDU & $3(2)$ & - & - & $2(7)$ & $1(3)$ \\
\hline Gender M, n (\%) & $58(47)$ & $22(49)$ & $8(44)$ & $13(46)$ & $15(47)$ \\
\hline Age, years, n (\%) & & & & & \\
\hline $18-30$ & $37(30)$ & $13(29)$ & $7(39)$ & $8(29)$ & $9(28)$ \\
\hline $31-40$ & $45(37)$ & $17(38)$ & $6(33)$ & $9(32)$ & $13(41)$ \\
\hline $41-50$ & $22(18)$ & $8(18)$ & $4(22)$ & $4(14)$ & $6(19)$ \\
\hline$\geq 51$ & $19(15)$ & $7(15)$ & $1(6)$ & $7(25)$ & $4(12)$ \\
\hline $\begin{array}{l}\text { Disease duration, } \\
\text { years, } \mathrm{n}(\%)\end{array}$ & & & & & \\
\hline$<1$ & $5(4)$ & $3(7)$ & $1(6)$ & $1(4)$ & $0(0)$ \\
\hline $2-10$ & $66(54)$ & $22(49)$ & $12(66)$ & $16(57)$ & $16(50)$ \\
\hline $11-20$ & $38(31)$ & $16(35)$ & $5(28)$ & $8(29)$ & $9(28)$ \\
\hline$\geq 21$ & $14(11)$ & $4(9)$ & $0(0)$ & $3(10)$ & $7(22)$ \\
\hline Medication, n (\%) & & & & & \\
\hline
\end{tabular}




\begin{tabular}{|c|c|c|c|c|c|}
\hline immunosuppression & $107(87)$ & $34(76)$ & $15(83)$ & $28(100)$ & $30(94)$ \\
\hline biological & $61(50)$ & $19(42)$ & $9(50)$ & $17(61)$ & $16(50)$ \\
\hline steroid & $33(27)$ & $9(20)$ & $6(33)$ & $10(36)$ & $8(25)$ \\
\hline $\begin{array}{l}\text { Baseline FC, } \\
\text { median (range) }\end{array}$ & $\begin{array}{l}48(5- \\
3137)\end{array}$ & $7(5-1215)$ & $40(5-2899)$ & $\begin{array}{l}85(5- \\
1038)\end{array}$ & $40(5-3137)$ \\
\hline $\begin{array}{l}\text { Baseline symptom } \\
\text { score, median } \\
\text { (range) }{ }^{b}\end{array}$ & $1.2(0-8)$ & $1.4(0-4)$ & $0.9(0-3)$ & $1.2(0-6)$ & $1.4(0-8)$ \\
\hline $\begin{array}{l}\text { Baseline VAS, } \\
\text { median (range) }^{c}\end{array}$ & $2.2(1-7)$ & $2.7(1-7)^{a}$ & $1.8(1-5)^{\mathrm{a}}$ & $2.2(1-5)$ & $3.0(1-7)$ \\
\hline $\begin{array}{l}\text { Baseline 15D score, } \\
\text { median (range) }{ }^{d}\end{array}$ & $\begin{array}{c}0.928 \\
(0.551-1)\end{array}$ & $\begin{array}{c}0.911(0.551- \\
1)\end{array}$ & $\begin{array}{c}0.955 \\
(0.814-1)\end{array}$ & $\begin{array}{c}0.910 \\
(0.670-1)\end{array}$ & $\begin{array}{c}0.926 \\
(0.704-1)\end{array}$ \\
\hline
\end{tabular}

$\mathrm{FC}=$ fecal calprotectin

VAS=visual analog scale

${ }^{\mathrm{a}} \mathrm{p}<0.05$

${ }^{\mathrm{b}}$ scale $0-15$, higher score worse

${ }^{c}$ scale 1-7, higher score worse

${ }^{\mathrm{d}}$ scale 0-1, lower score worse 
Table 2. Results of the symptom questionnaire and health related quality of life

\begin{tabular}{|c|c|c|c|c|c|c|}
\hline \multirow[t]{2}{*}{$\begin{array}{l}\text { Time, } \\
\text { months }\end{array}$} & \multicolumn{2}{|c|}{$\begin{array}{l}\text { symptom score, mean } \\
\text { (scale } 0-15, \text { higher } \\
\text { worse) }\end{array}$} & \multicolumn{2}{|c|}{$\begin{array}{c}\text { VAS, mean } \\
\text { (scale } 0-7, \text { higher worse) }\end{array}$} & \multicolumn{2}{|c|}{$\begin{array}{c}\text { 15D score, mean } \\
\text { (scale } 0-1, \text { lower worse) }\end{array}$} \\
\hline & $\begin{array}{l}\text { Home } \\
\text { monitoring } \\
\text { (n) }\end{array}$ & $\begin{array}{l}\text { Control } \\
\text { (n) }\end{array}$ & $\begin{array}{l}\text { Home } \\
\text { monitoring } \\
\text { (n) }\end{array}$ & $\begin{array}{l}\text { Control } \\
\text { (n) }\end{array}$ & $\begin{array}{l}\text { Home } \\
\text { monitoring } \\
\text { (n) }\end{array}$ & $\begin{array}{l}\text { Control } \\
\text { (n) }\end{array}$ \\
\hline $\mathbf{0}$ & $1.0(62)$ & $1.3(59)$ & $2.2(62)$ & $2.5(59)$ & $0.926(62)$ & $0.929(58)$ \\
\hline 2 & $1.2(47)$ & 2.2 (19) & $2.2(47)$ & 2.1 (19) & $0.941(33)$ & $0.941(27)$ \\
\hline 4 & $1.3(37)$ & $1.0(14)$ & $2.2(37)$ & $1.6(14)$ & $0.943(28)$ & $0.945(23)$ \\
\hline 6 & $0.9(35)$ & $1.1(21)$ & $1.9(35)$ & $1.9(21)$ & 0.937 (31) & $0.935(26)$ \\
\hline 8 & $1.3(32)$ & $1.1(14)$ & $1.9(32)$ & $1.9(14)$ & $0.934(23)$ & 0.940 (19) \\
\hline 10 & $1.0(26)$ & $0.7(10)$ & $2.0(26)$ & $2.0(10)$ & 0.931 (19) & $0.922(16)$ \\
\hline 12 & 0.9 (19) & $0.8(9)$ & 2.0 (19) & $2.0(9)$ & 0.919 (15) & $0.929(11)$ \\
\hline extra 1 & $3.2(4)$ & $2.9(11)$ & $3.3(4)$ & $3.2(11)$ & $0.908(9)$ & $0.908(10)$ \\
\hline extra 2 & $1.5(2)$ & $1.3(5)$ & $2.0(2)$ & $2.2(5)$ & $0.965(2)$ & $0.912(4)$ \\
\hline extra 3 & - & $3.0(2)$ & - & $3.0(2)$ & 0.929 (1) & 0.909 (2) \\
\hline
\end{tabular}

The home monitoring patients completed the questionnaires in every other month, and the control group at the baseline, 6 months, and 12 months, and at the appointment to the gastroenterology unit. 
Table 3. The influence of the home-monitoring to the disease course.

\begin{tabular}{|c|c|c|c|c|}
\hline & Total & $\begin{array}{c}\text { Home } \\
\text { monitoring } \\
\text { group }\end{array}$ & Control group & $\mathrm{p}$ \\
\hline $\begin{array}{l}\text { Relapses (according to } \\
\text { the symptom score) }\end{array}$ & 46 & 25 & 21 & 0.521 \\
\hline Hospitalizations & 6 & $4^{\mathrm{a}}$ & 1 & - \\
\hline $\begin{array}{l}\text { Outpatient clinic visits } \\
(\mathrm{n}=119 \text { patients }) \\
\text { per patient, mean } \\
\text { (range) }\end{array}$ & $2.3(0-7)$ & $\begin{array}{c}127 \\
2.0(0-6)\end{array}$ & $\begin{array}{c}154 \\
2.6(0-7)\end{array}$ & 0.022 \\
\hline $\begin{array}{l}\text { Laboratory visits } \\
\text { ( } \mathrm{n}=123 \text { patients) } \\
\text { per patient, mean } \\
\text { (range) }\end{array}$ & $6.5(1-20)$ & $\begin{array}{c}392 \\
6.5(1-18)\end{array}$ & $\begin{array}{c}411 \\
7.3(2-20)\end{array}$ & 0.636 \\
\hline $\begin{array}{l}\text { E-mails ( } n=54 \text { patients) } \\
\text { per patient, mean } \\
\text { (range) }\end{array}$ & $\begin{array}{c}210 \\
3.8(1-26)\end{array}$ & $\begin{array}{c}69 \\
2.8(1-11)\end{array}$ & $\begin{array}{c}141 \\
4.9(1-26)\end{array}$ & 0.180 \\
\hline $\begin{array}{l}\text { Phone calls ( } \mathrm{n}=64 \\
\text { patients) } \\
\text { per patient, mean } \\
\text { (range) }\end{array}$ & $\begin{array}{c}182 \\
1.5(0-14)\end{array}$ & $\begin{array}{c}95 \\
1.5(0-14)\end{array}$ & $\begin{array}{c}87 \\
1.5(0-11)\end{array}$ & 0.423 \\
\hline
\end{tabular}

a 1 home monitoring patient was treated in hospital twice 
Figure 1. Flow chart of the patients

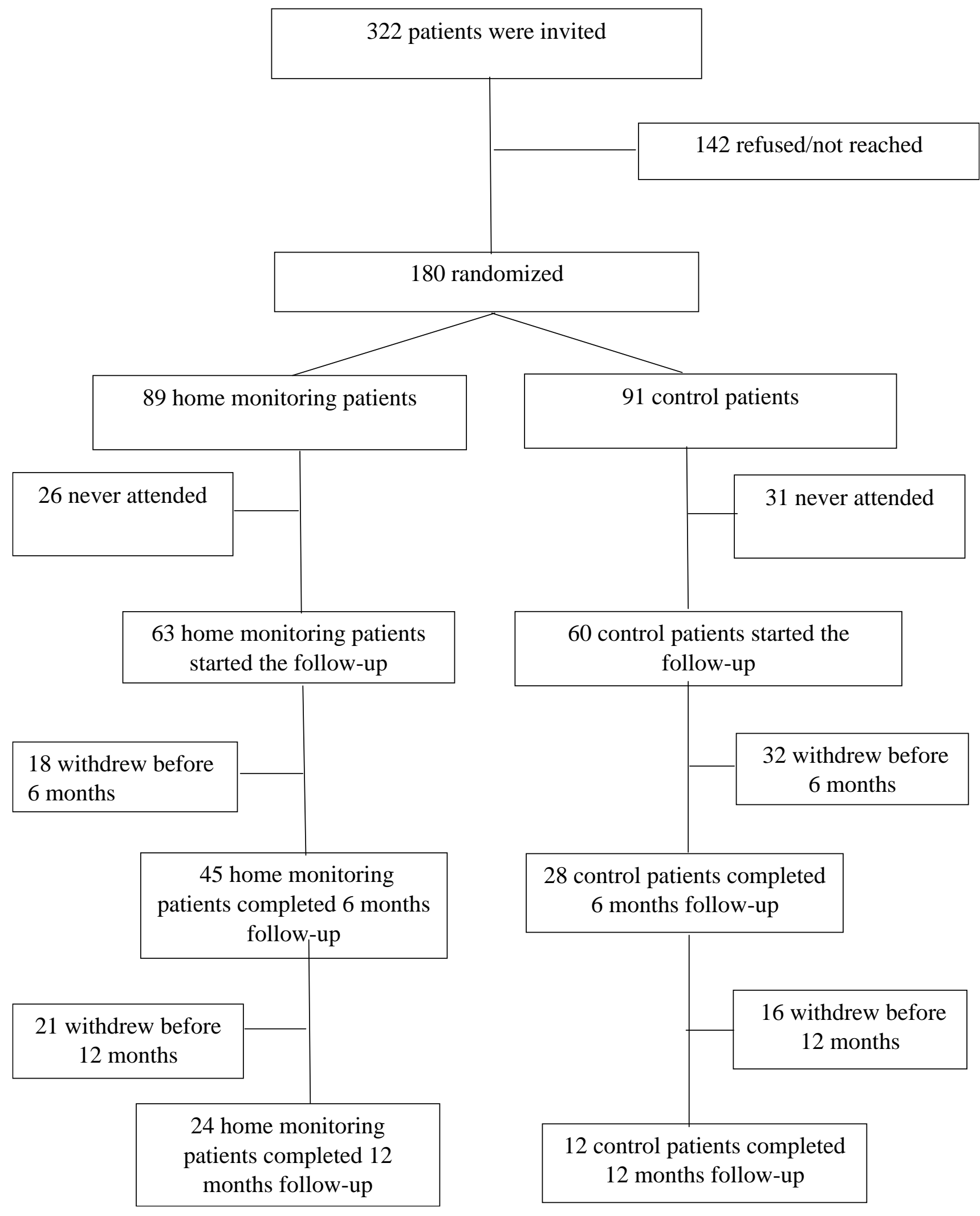


Figure 2. Compliance of all the included patients (Kaplan-Meier curve)

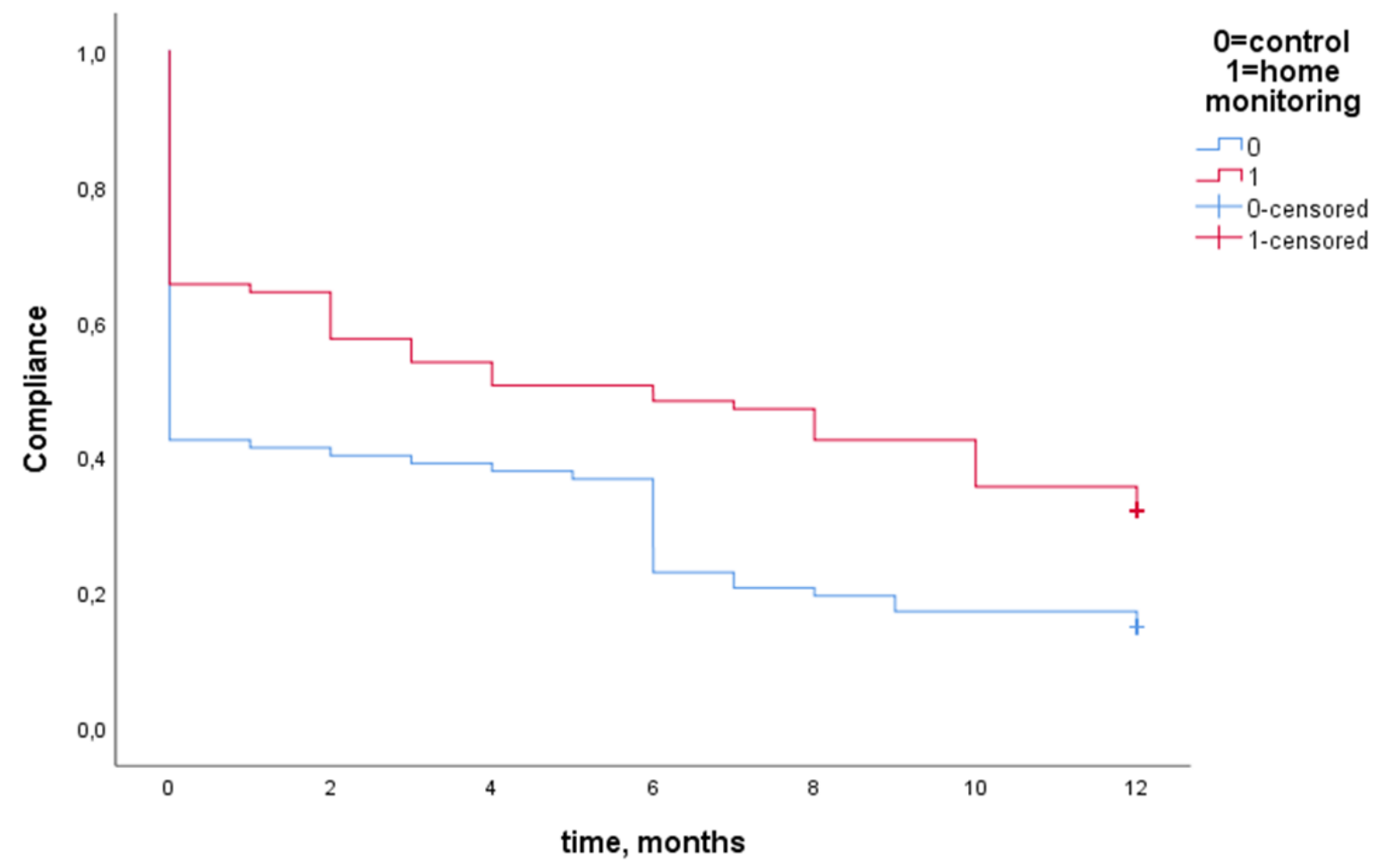

